\title{
Leadership, Management and Organisational Development
}

\author{
Richard Bolden, Professor of Leadership and Management, UWE, Bristol \\ In Gold, J., Thorpe, R and Mumford, A. (eds) (2010) Handbook of Leadership and \\ Management Development. Aldershot: Gower.
}

\begin{abstract}
Introduction
In this chapter I suggest that leadership, management and organisational development are all parts of the same process - namely enhancing the capacity of organisations, and the people within them to better achieve their purpose. As such, they are closely tied to strategic mission and all the systems that support it, as the Center for Creative Leadership Handbook for Leadership Development concludes: "to be fully effective, a development system must be integrated with the organization's other processes: management planning, performance management, job selection, reward and recognition systems, and even mistake systems. The confluence of these processes determines the relative effectiveness of any one development activity."
\end{abstract}

Despite the interdependence of these systems, however, they are often treated in relative isolation - as a series of discrete initiatives outsourced to different parts of the organisation (Human Resources (HR), Finance, Information and Communications Technology (ICT), etc.) - and consequently it is not surprising that many fail to deliver on their promise. Furthermore, leadership and management development (LMD) activities are often commissioned with little consideration of the underlying theories and assumptions on which they are based. Without an informed appreciation of the logic on which such initiatives are founded, however, and the proposed mechanism(s) by which they may lead to improved capacity and, in turn, enhanced performance it is unlikely that the desired outcomes will be achieved - to use the analogy "you reap what you sow"!

I begin this chapter by reviewing recent trends in LMD, before outlining the conceptual underpinnings of the most common approaches and exploring the relationship of LMD to other organisational development activities. The chapter concludes with a framework that can be used when considering which approach(es) to utilise, along with a number of recommendations on choosing a provider.

\section{Current trends in leadership and management development}

Management and executive education is big business, with an estimated $\$ 50$ billion spent per year on leadership development alone ${ }^{2}$. In a 2003 survey the Financial Times found leading European companies to be spending on average $£ 3,336$ per participant per year on executive education; $42 \%$ of respondents had a Corporate University (with a further $12 \%$ looking to establish one over the next couple of years); and of the topics offered leadership, followed by general management, were the most popular ${ }^{3}$.

Within Higher Education (HE) provision, there are now 117 members of the Association of Business Schools in the UK (up from just two in the whole country in the mid-1960s) and in the years between 1996/7 and 2006/7 the number of students of Business and Administrative studies rose by $40 \%$ (from 222,321 to 310,255 ) with the greatest rate of change for postgraduate students (up by $66 \%$ ), especially those on business and management programmes such as the MBA ${ }^{4}$.

Such trends are typical of the expanding global market for LMD - driven, in part, by the desire of educational providers to enter into what is seen to be a lucrative market and fuelled by political and corporate assertions about the value of effective leadership and the need to address a leadership and management 'skills gap'. From an employer perspective the primary triggers for investing in LMD are considered to be the rapidly changing nature of the external environment, closely followed by business needs and HR strategy, and students are increasingly regarding leadership and management related programmes as enhancing their employability and career prospects.

Despite an explosion in the provision of and demand for LMD, however, the link to improved 
performance remains inconclusive. Empirical research has remained unable to produce consistent evidence of either the relationship or the mechanisms by which it might occur. There are many reasons why this might be, including variations in the quality of provision, variable levels of integration with organisational processes, personal and contextual differences in the most appropriate forms of development and, even the possibility that such relationships are tenuous or inexistent. Whatever the cause, however, organisations are well advised to consider when and how to invest in LMD - after all, whilst it may be concluded that "there is strong statistical evidence that management development leads to superior performance across companies of all sizes, sectors and national location [...] an impressive 16 percent of variance is explained by three factors: the extent to which HR is integrated with business strategy, the degree to which the firm takes a thoughtful, long-term approach to developing managerial capability and the belief by line managers that their employer is taking management development seriously" ${ }^{5}$ - in effect, factors outside the classroom.

Increasing dissatisfaction with traditional approaches to LMD, along with an expanded marketplace, changing business challenges and advances in leadership theory, development and practice have led to a diversification in the range of programmes and initiatives on offer. In particular there has been increasing demand for postgraduate and short course or executive education within university provision; greater modularisation, flexibility and workbased learning from all providers; and more informal and personalised development (such as mentoring, coaching, $360^{\circ}$ feedback, project assignments, action learning sets and team facilitation) - see Table 1.

\begin{tabular}{|c|c|c|}
\hline Key Trends & From & To \\
\hline $\begin{array}{l}\text { Type of } \\
\text { provision }\end{array}$ & $\begin{array}{l}\text { - Prescribed course } \\
\text { - Standardized } \\
\text { - Theoretical/academic }\end{array}$ & $\begin{array}{l}\text { - Intervention/development programme } \\
\text { - Customized } \\
\text { - Applied/based on real-life challenges }\end{array}$ \\
\hline Time-frame & $\begin{array}{l}\text { - One-off } \\
\text { - Discrete start \& end points }\end{array}$ & $\begin{array}{l}\text { - Continual } \\
\text { - An ongoing development 'journey' }\end{array}$ \\
\hline Format & $\begin{array}{l}\text { - Didactic: lectures \& } \\
\text { presentations } \\
\text { - Abstract/conceptual }\end{array}$ & $\begin{array}{l}\text { - Participatory: interactive activities \& } \\
\text { group work } \\
\text { - Experiential/reflective }\end{array}$ \\
\hline Location & $\begin{array}{l}\text { - Classroom-based } \\
\text { - Off-site }\end{array}$ & $\begin{array}{l}- \text { Blended (variety of methods) } \\
\cdot \text { - Work-based as well as off-site } \\
\end{array}$ \\
\hline Focus & $\begin{array}{l}\text { - Development of individuals } \\
\text { - Generic }\end{array}$ & $\begin{array}{l}\text { - Development of individuals \& groups } \\
\text { - Vocational/for a specific purpose }\end{array}$ \\
\hline $\begin{array}{l}\text { Role of } \\
\text { provider }\end{array}$ & $\begin{array}{l}\text { - Supplier } \\
\text { - Expert }\end{array}$ & $\begin{array}{l}\text { - Partner, collaborator \& coach } \\
\text { - Co-designer/facilitator }\end{array}$ \\
\hline $\begin{array}{l}\text { Nature of } \\
\text { support }\end{array}$ & $\begin{array}{l}\text { - Limited } \\
\text { - Primarily concerned with } \\
\text { accreditation } \\
\text { - Theoretical/academic }\end{array}$ & $\begin{array}{l}\text { - Extensive - relationship management } \\
\text { - Primarily concerned with client } \\
\text { experience } \\
\text { - Coaching/mentoring }\end{array}$ \\
\hline
\end{tabular}

Table 1 - Changing trends in leadership development ${ }^{6}$

Such trends pose major practical and developmental challenges to providers of LMD. Firstly, alongside the modularisation of formal programmes into 'bite size chunks' there is increasing pressure to provide holistic programmes applicable to leaders and managers at all levels of the organisation. Secondly, the increase in personalised learning and customization of programmes poses serious resourcing challenges through the increased time required for developing and supporting provision and the high level of practical expertise required by staff. And thirdly, with the shift away from traditional career structures and employment arrangements managers are increasingly expected to determine and address their own development needs rather than being directed to provision via their employer (hence increasing the need for promotion and legitimisation of development activities) ${ }^{7}$.

Given the difficulty in implementing the changes highlighted above it is perhaps not surprising, therefore, that most HE provision remains in a traditional face-to-face, classroom mode and that where approaches such as e-learning are utilised this tends to be to support rather than replace traditional education (e.g. via a 'blended' approach). Furthermore, whilst employers clearly place great value on work-based learning much of this remains ad-hoc rather than via formalised job rotation, placements, exchanges and assignments. 
Whilst much leadership development remains focussed on the acquisition of knowledge and skills, however, it is proposed that one of the main benefits for practicing managers is the opportunity for reflection. For managers in fast-paced and demanding jobs, leadership development can offer a protected space in which they can take time to slow-down and reflect on past, current and future events - a period of calm in which they can regroup and reenergise for the challenges ahead - although, as John Storey argues, there may well be insufficient time allocated to this.

"There is a fundamental dilemma that haunts many leadership development events. Because leadership is perceived as fundamentally about 'doing' rather than 'knowing', there is an inherent bias towards activity-focussed and indeed briskly paced encounters [...] In consequence, there is little time for reflection or strategic thinking. These characteristics of leadership development events are self-evidently in tension with the kind of clear thinking supposedly required of top leaders."

The key to successful leadership development, it would appear, is achieving an appropriate balance between knowledge-exchange, action and reflection, and alignment between the needs and wants of the individual and those of the organisation. From an extensive review of the literature Burgoyne, Hirsh and Williams conclude: "the evidence on how management and leadership works is that it works in different ways in different situations. The practical implication of this is that to get the benefit of management and leadership development requires the design of appropriate approaches for specific situations rather than the adoption of a universal model of best practice" ${ }^{\prime \prime}$ - a case of not so much what you do but how you do it.

$360^{\circ}$ feedback, for example, although increasingly en vogue, like many approaches is found to be most effective when integrated within a comprehensive development programme and is significantly affected by the following three factors: (1) a work context supportive of skills development, (2) the belief of the participant that people can improve their skills, and (3) a belief that they themselves are capable of improving and developing ${ }^{10}$. Indeed, factors contributing positively towards individual development performance across all approaches include (1) opportunities for receiving and discussing individual feedback; (2) the quality of management processes preceding, supporting and reinforcing development activities; (3) the extent to which they are tailored to personal requirements; and (4) the extent to which they draw on and develop personal experience ${ }^{11}$.

Thus, the choice of development approach is not a simple one. For maximum effect, we need to carefully consider what it is that we seek to develop and how best this can be achieved. If, for example, we wish to develop a culture of shared, considerate and reflective leadership within our organisation is it wise just to send individual 'leaders' on action-packed or highly prescriptive leadership training courses? Robert $\mathrm{Chia}^{12}$ recounts a Japanese management development programme for high-potential leaders that adopts a rather different approach they were taken to a retreat in the mountains and encouraged to learn the art of tea pouring and observing the movement of carp. Such a programme, it is argued, sought to develop a sensitivity, self-discipline and capacity for pattern recognition that could not be achieved through more mainstream approaches. A clearly espoused theory of change that leads to desirable forms of behaviour, linked to ongoing monitoring and evaluation of impact(s) is increasingly deemed a crucial factor influencing the success of an LMD intervention.

It is also worth noting that the LMD process serves many purposes beyond simply developing talent. Executive education can be an effective retention strategy that helps maintain the motivation, enthusiasm and commitment of participants; it can serve as a reward; and can also help in teambuilding and engendering a sense of shared purpose. On the flipside, singling out certain individuals over others for involvement in LMD can lead to unintended consequences such as disappointment, alienation and resistance - little can be more demotivating than having a colleague or superior go off on all-expenses-paid trip only to try to change everything and tell you how to do your job better upon their return!

\section{Theoretical perspectives on LMD}

The trends and challenges outlined above point towards a number of competing pressures and purposes for LMD. There are, of course, the practical concerns of creating more effective managers and leaders, enhancing the competitiveness of organisations and providing programmes that people will pay for, but associated with these are a number of rather diverse 
philosophical perspectives on the role of management and leadership within organisations and how best to develop them.

David Holman ${ }^{13}$ has identified four contrasting models of management education, each founded upon differing philosophical beliefs about the nature of knowledge, learning, and the role of managers (see Table 2). In outlining these perspectives he argues that 'academic liberalism' and 'experiential vocationalism' are somewhat wanting as approaches to the development of practicing managers - the former due to its over-reliance on theory and the latter for its over-reliance on action - proposing instead that 'experiential liberalism' and 'experiential/critical' approaches are most likely to create managers capable of meeting the future needs of organisations and society. Their experiential methods go a long way to promoting learning and development because of the way in which they build upon how managers naturally learn at work and their ability to address the complexities of actual management practice. They are also likely, however, to produce managers who are more questioning of traditional authority and prepared to challenge organisational vision, values and practices. Clearly the perspective chosen will have major impacts on the kinds of management and leadership capacity developed within organisations yet, despite this, remarkably few LMD initiatives explicitly articulate what constitutes an effective manager or leader, or the educational processes associated with their development ${ }^{14}$.

\begin{tabular}{|c|c|c|c|}
\hline Approach & Main assumptions & Main aims & Teaching methods \\
\hline $\begin{array}{l}\text { Academic } \\
\text { liberalism }\end{array}$ & $\begin{array}{l}\text { Management education is } \\
\text { concerned with the pursuit of } \\
\text { objective knowledge about } \\
\text { management that can be applied in } \\
\text { a relatively scientific and rational } \\
\text { manner. }\end{array}$ & $\begin{array}{l}\text { To create the } \\
\text { management } \\
\text { scientist, capable of } \\
\text { analysis and the } \\
\text { application of } \\
\text { theoretical principles. }\end{array}$ & $\begin{array}{l}\text { Primary teaching } \\
\text { methods include } \\
\text { lectures, seminars, case } \\
\text { studies and } \\
\text { experimentation. }\end{array}$ \\
\hline $\begin{array}{l}\text { Experiential } \\
\text { liberalism }\end{array}$ & $\begin{array}{l}\text { Shares many of the same } \\
\text { assumptions as academic } \\
\text { liberalism but argues for a more } \\
\text { applied approach, grounded in } \\
\text { managerial experience rather than } \\
\text { theory. }\end{array}$ & $\begin{array}{l}\text { To create the } \\
\text { reflective } \\
\text { practitioner } \\
\text { equipped with } \\
\text { appropriate practical } \\
\text { skills and knowledge } \\
\text { and the ability to } \\
\text { adapt to and learn } \\
\text { from the situation. }\end{array}$ & $\begin{array}{l}\text { Primary teaching } \\
\text { methods would include } \\
\text { group work, action } \\
\text { learning and self } \\
\text { development. }\end{array}$ \\
\hline $\begin{array}{l}\text { Experiential } \\
\text { vocationalism }\end{array}$ & $\begin{array}{l}\text { Arises from economic and } \\
\text { organisational concerns to argue } \\
\text { that the main role of management } \\
\text { education is to provide managers } \\
\text { with the relevant skills and } \\
\text { knowledge required by } \\
\text { organisations. }\end{array}$ & $\begin{array}{l}\text { To create the } \\
\text { competent manager } \\
\text { equipped with the } \\
\text { necessary } \\
\text { interpersonal and } \\
\text { technical } \\
\text { competencies } \\
\text { required by } \\
\text { organisations. }\end{array}$ & $\begin{array}{l}\text { Primary teaching } \\
\text { methods would include } \\
\text { competence based } \\
\text { approaches such as the } \\
\text { National Occupational } \\
\text { Standards in } \\
\text { Management and } \\
\text { Leadership. }\end{array}$ \\
\hline $\begin{array}{l}\text { Experiential/ } \\
\text { critical }\end{array}$ & $\begin{array}{l}\text { Seeks to "emancipate managers } \\
\text { and other employees in the } \\
\text { organisation from oppression and } \\
\text { alienation" (Holman, 2000: 208). It } \\
\text { has much in common with } \\
\text { experiential liberalism although } \\
\text { demands a more critical level of } \\
\text { reflection that enables people to } \\
\text { become reflexive about their own } \\
\text { knowledge and actions and to } \\
\text { formulate practical, non- } \\
\text { instrumental and emancipative } \\
\text { forms of action. }\end{array}$ & $\begin{array}{l}\text { To create the critical } \\
\text { practitioner able to } \\
\text { challenge and } \\
\text { develop new modes } \\
\text { of action. }\end{array}$ & $\begin{array}{l}\text { Primary teaching } \\
\text { methods would include } \\
\text { approaches } \\
\text { incorporating critical } \\
\text { action learning and } \\
\text { critical reflection. }\end{array}$ \\
\hline
\end{tabular}

Table 2 - Models of Management Education (Adapted from Holman, 2000)

Another area of confusion in this field is the similarity and difference between 'leadership' and 'management' development. In the discussion so far the terms have been used largely interchangeably as there is a significant degree of overlap but what exactly is leadership (as opposed to management) development and how can individuals and organisations get the most out of it? 
Day ${ }^{15}$ argues that leadership development is distinct from management development to the extent in which it involves preparing people for roles and situations beyond their current experience. Whilst management development equips managers with the knowledge, skills and abilities to enhance performance on known tasks through the application of proven solutions, leadership development seeks to build capacity to deal with unforeseen challenges. He goes on to make a further distinction between leader and leadership development, whereby leader development is about developing individuals in leadership roles, whilst leadership development is concerned with the development of the collective leadership capacity of the organisation. "In this way, each person is considered a leader, and leadership is conceptualised as an effect rather than a cause. Leadership is therefore an emergent property of effective systems design. Leadership development from this perspective consists of using social (i.e. relational) systems to help build commitments among members of a community of practice." ${ }^{\prime 16}$ Hence 'leader development' can be considered primarily as an investment in the human capital of selected individuals, whereas 'leadership development' is an investment in social capital via the nurturing of interpersonal networks, cooperation and collaboration within and between people and organisations. Both are important, although traditionally development programmes have focussed almost exclusively on the former.

Whilst Day's distinction is helpful in drawing attention to the wider social dynamics of leadership, the boundary between leader, manager and, infact, personal development remains blurred - participants on development programmes are usually managers and during their studies may well build and extend social networks for themselves and their organisations. There is a risk, therefore, that leadership development could be viewed as any understanding that develops individual(s) and that all development activities could be regarded as equally effective. Campbell, Dardis and Campbell ${ }^{17}$ argue that the field of leadership development is currently dominated by individualistic approaches that seek to enhance the intrapersonal attributes, interpersonal qualities, cognitive abilities, communication skills and task-specific skills of individual participants. At the intrapersonal level they argue, however, that "there is little reason to label this leadership development, except in the broad sense that the developing individuals hold leadership positions" ${ }^{\prime 1}$. The inter-personal level fits more closely with the notion of leadership development as a social influence process, whilst the additional three categories (cognitive, communication and taskspecific skills) are a range of personal capabilities that help enhance an individual's interpersonal influence. In each case a challenge remains as to how to differentiate the types of skills required by 'leaders' as opposed to 'managers' and/or 'followers' and the response remains largely dependent on one's theoretical and philosophical views on the nature of leadership. Campbell and colleagues own view is that the primary aim of leadership development is to enhance interpersonal influence over and above that which stems directly from a person's positional authority or legitimate power, and that the development of core influencing skills (including values that can serve as a 'moral compass', problem-defining and problem-solving skills, task facilitation skills, and communication and motivational skills) should be the main focus.

In our own experience of developing leaders at the Centre for Leadership Studies we take the view that it is important to develop all of these skills with a contextual appreciation of the cultural and organisational environment. When considering leadership, rather than management, development the primary emphasis is on enabling people to think beyond the apparent restrictions of their current role and to develop the critical capabilities to move between operational and strategic modes as required - to balance an attention for detail with an understanding of the bigger picture. "All in all, leadership development within management education should develop the 'character', integrity, skills and discursive intelligence necessary for the responsible exercise of power."19

To this extent, leadership development may well incorporate elements of more typical management and self-development programmes (including time management, planning, delegation and self-awareness) but with the objective of creating a reflexive space in which the leader/manager can critically reflect upon their current practice and experience. There is no reason to consider, therefore, that leadership development should only be offered to senior managers and, indeed, there would be good reason to encourage this kind of development opportunity throughout the organisation to enhance collective as well as individual capacity. The nature of the required intervention, however, is likely to vary according to the job role, experience and personal abilities/attributes of participants. 


\section{Choosing an LMD approach}

With the array of development initiatives on offer, the differing theoretical perspectives that inform them, and the wide range of providers in the marketplace, the practical issue of deciding which to select can be overwhelming. From extensive experience of working with management and leadership development over many years and in different contexts Jonathan Gosling and Henry Mintzberg propose seven basic tenets upon which management (including leadership) education should be built ${ }^{20}$ :

1. Management education should be restricted to practicing managers, selected on the basis of performance.

2. Management education and practice should be concurrent and integrated.

3. Management education should leverage work and life experience.

4. The key to learning is thoughtful reflection.

5. Management development should result in organisation development.

6. Management education must be an interactive process.

7. Every aspect of the education must facilitate learning.

The implications of these tenets are manifold both for those purchasing and participating in management and leadership development as well as those providing it. Of particular significance is the emphasis on the interplay between practice and reflection, individual and organisational development, and the provider and participant. Gosling and Mintzberg argue "there is a certain quality of conversation that takes place in a well-managed classroom that is almost unique, where the fruits of experience, theory and reflection are brought together into a new understanding and commitment." ${ }^{21}$

This approach argues for increased dialogue and partnership between companies and LMD providers that enhances the depth of conversation about the nature of management and organisation. Leadership development, particularly the opportunity to step back and reflect upon practice, should be built into all aspects of organisational functioning. Development doesn't just occur in the classroom - there are opportunities to learn from just about everything and, indeed as many large organisations now recognise through their application of the 70-20-10 principle 22 , a richness and diversity of learning is pivotal to developing balanced, reflective, yet decisive leadership as and when required

So, on this basis what can we do to ensure that we get the most out of leadership development? From a review of the literature Yukl $^{23}$ proposes that conditions for successful leadership training include: clear learning objectives; clear, meaningful content; appropriate sequencing of content; appropriate mix of training methods; opportunity for active practice; relevant, timely feedback; high trainee self-confidence; and appropriate follow-up activities. Thus, as indicated earlier, a well considered approach that clearly articulates how particular interventions will impact upon management and leadership capacity and, in turn, influence individual and organisational performance is most likely to yield effective results. The content and style of the preferred intervention, however, will vary according to the context as the following nine points for reflection will clarify.

(1) Critically evaluate current conceptions of the nature of leadership and learning within your organisation. As discussed earlier you tend to reap what you sow - if development and reward systems favour individual recognition over collective action then they are unlikely to result in a culture that encourages collaboration and shared leadership.

(2) Think carefully about the development needs of both individuals and the organisation: "needs analysis provides the crucial information to ensure that professional learning is appropriate, valid and relevant" ${ }^{\prime 24}$. Consider ways in which the impact of development can be evaluated from a range of perspectives; how benefits can be optimised both for individuals and the organisations they serve; and how development needs may change over time.

(3) On the basis of these considerations, explore a range of development options from a number of providers. Enter into a discussion with providers to see how programmes could be tailored to your requirements; how they could maximise the benefits of experiential and reflective learning; and how the learning can be transferred and sustained within the workplace. Approaches that integrate a variety of learning methods are particularly effective, especially when combined with opportunities for receiving and discussing individual feedback. 
(4) Ensure that learning and development are recognised as essential and valued activities within your organisation and that everyone is encouraged and supported in their learning. The quality of management processes preceding and following development activities are a key predictor of impact and instrumental in ensuring that newly learned competencies are put into practice.

(5) Review other organisational systems and processes (especially HR) and how these interface with and support LMD. Research evidence indicates that the manner in which HR practices are implemented is a greater predictor of success than which practices are adopted. A sophisticated approach that enables one to 'go the extra mile' is most likely to be effective: "those organisations with the Big Idea that were value-led and managed were much more likely to sustain their organisational performance over the long-term"25.

(6) Identify and reduce personal barriers to learning and the exercise of leadership. There are a range of psychological barriers to effective leadership, including low self-esteem, lack of self confidence, fear of failure or disapproval, cognitive 'constriction' and adverse consequences of stress. To overcome these, a range of techniques including desensitisation, reinforcement, psychological re-enactment, social skills development and group dynamics may be used ${ }^{26}$.

(7) Consider the role and impact of organisational culture and context. What is the nature of the task? How experienced and able are employees? And what are appropriate ways of conceiving of performance? In many sectors, focussing on economic outcomes alone is wholly inappropriate. What drives people to work in healthcare, education or the military are quite different from one another, and from more commercially-orientated sectors. To engage, motivate and inspire people, goals and objectives must be couched in culturally appropriate values and language.

(8) Take an appreciative rather than deficit approach to development. Build upon strengths that already exist and find ways of working with or around weaknesses. The key to effective leader development is not filling in gaps in competency, but nurturing a unique and genuine approach to leadership ${ }^{27}$. Consider too the importance of continuity in the change process - there may be a time and place for dramatic transformation, but in the majority of cases a more subtle and considered approach that builds upon existing individual, group and organisational capabilities is what is required.

(9) Finally, take the long-term view to leadership and organisational development. In creating genuine and sustainable leadership within organisations there is no quick fix (despite what some providers may promise!). A series of initiatives following the latest management fads is more likely to engender a climate of cynicism than engagement. 'Leadership' too, has suffered at the hands of faddism, with each guru stating their 7, 8, 9 or 10 principles more vociferously than the last. It pays to be selective and critical in what you sign up to and to consider how development activities fit within the longer-term life and career span of organisations and individuals.

\section{An integrated approach to leadership, management and organisational development}

So far in this chapter I have focussed specifically on the development of individual managers and leaders as well as the development of the more relational and collective aspects of leadership. What is evident, however, from this review is the dynamic interplay between each of these factors and the wider organisational context. It is clear, for example, that developing individual leaders in isolation is unlikely to be sufficient to improve leadership across the entire organisation. Furthermore, building networks and relationships may prove unproductive if the individuals within them do not have the necessary knowledge, skills or competence to exert influence, or find themselves faced with inflexible and unsupportive organisational structures.

Many authors now recognise the interdependent nature of organisational systems and processes and the key role played by people in leadership roles. Purcell et al., for example, in their analysis of HR practices recognise the central role of first line managers (FLMs) in moderating employee experience:

"It is clear that the crucial link is between the employee experiences of people management, the formation or modification of attitudes towards the employing organisation and the job, and the inducement these provide to engage in certain 
types of discretionary behaviour, It is not, however, simply the quality of HR practices per se which causes this chain reaction, but crucially the way in which FLMs apply these practices. Employees' experience of these is inexorably linked with their relationship with their FLM who is seen as the agent of the organisation and the deliverer of the people management practices." 28

Hence the paradox is that LMD (and other forms of organisational development) are more likely to be successful where leadership and management is already effective than where it is problematic. The question, therefore, for those people involved in such activities is how to create a virtuous cycle whereby individual, team and organisational practices and performance become mutually reinforcing. Whether or not LMD and other organisational processes are aligned, they each transmit powerful messages about what the organisation values and rewards, and where messages are consistent they are far more likely to drive desired behaviours.

The final part of this chapter presents an integrated framework for leadership and organisational development developed from an extensive review of leadership theory and practice $^{29}$. It does not claim to be comprehensive, but rather to serve as a map of the terrain, identifying some key milestones and landmarks that should be of value to those exploring this area. The model, shown in Figure 1, is not to be regarded as static but in a continual state of flux, whereby each element informs and influences the others. It incorporates three levels (individual, group/team and organisation) and series of five steps (direction setting, structures and processes, leadership development, learning transfer, and evaluation and review). For each step a series of key factors are highlighted, along with some key questions to consider. The entire model is embedded within a broader context which should be considered when determining appropriate forms of action. In presenting this model, the intent is that it be used as a structure for facilitating discussion and reflection rather than as a prescriptive framework for deciding on a leadership development approach.

(1) The first step of the model is labelled direction setting and is underpinned by the processes of dialogue, understanding and creating shared purpose. At an individual level this involves identifying motivations, ambitions, identity, personal strengths and weaknesses. It is summed up by questions such as "who am I?" and "why am I here?" These can be deeply philosophical questions and may remain with the individual throughout the leadership development process if not their whole life. At a group and organisational level it involves identifying a common and connecting set of values, objectives, shared identity and strategic priorities. It is about how groups and organisations determine who/what they are and what they seek to achieve. Such expressions may be captured in ethics or value statements, organisational mission, business plans and group norms, and define the ultimate purpose, and hence desirable form, of leadership within the group/organisation.

(2) The second step involves examining structures and processes and incorporates a review of systems, roles and functions. At an individual level this means focussing on formal and informal roles (both within and outside the organisation), career progression and development opportunities, networks and relationships (again within and beyond the organisation), and an in-depth and practical understanding of how the system works - such a perspective should help reveal any barriers, conflicts and sources of support for takingon/developing a leadership role. At a group level it involves considering the distribution of expertise and issues relating to the social dynamics of the work group and how various tasks are distributed. At the organisational level it involves reviewing how HR practices, resource allocation, communication processes, management and leadership approach, and partnership working influences the distribution of power and any resistance to change within the system.

(3) The third step, leadership development, corresponds to the actual process of enhancing the leadership capacity of individuals, groups and the wider organisation. For individuals this involves offering opportunities for learning, reflection and experimentation that builds on and extends prior experience. Whilst an element of this may be about straight skills and knowledge acquisition, it must also go deeper so as to engage with the bigger questions and issues raised in steps one and two. At the group level it involves building and strengthening relationships, trust and commitment. At the organisational level this requires the integration of organisational development, management development and leadership development. It may occur at a number of levels, through multiple channels, be associated with organisational change, and involve longer-term planning for staff development and succession. Ultimately 


\begin{tabular}{|c|c|c|c|}
\hline & INDIVIDUAL & GROUP/TEAM & ORGANISATION \\
\hline CONTEXT & $\begin{array}{l}\text { - Occupation } \\
\text { - Personality } \\
\text { - Life experience }\end{array}$ & $\begin{array}{l}\text { - Task /function } \\
\text { - Group membership } \\
\text { - History }\end{array}$ & $\begin{array}{l}\text { - Socio-political } \\
\text { - Economic } \\
\text { - Sector/activity }\end{array}$ \\
\hline $\begin{array}{l}\text { DIRECTION } \\
\text { SETTING }\end{array}$ & $\begin{array}{l}\text { - Personal aims, motivations } \\
\text { \& ambitions } \\
\text { - Personal identity } \\
\text { - Needs analysis: strengths } \\
\text { \& weaknesses }\end{array}$ & $\begin{array}{l}\text { - Nature of group (project } \\
\text { team, partnership, etc.) } \\
\text { - Group aims and objectives } \\
\text { - Social/group identity }\end{array}$ & $\begin{array}{l}\text { - Values: ethics, principles } \\
\text { - Objectives: economic, } \\
\text { social, other } \\
\text { - Strategic priorities } \\
\text { - Org culture \& identity }\end{array}$ \\
\hline Key Questions & $\begin{array}{l}\text { Who am I \& why am I } \\
\text { here? }\end{array}$ & $\begin{array}{l}\text { Who are "we" and who are } \\
\text { "they"? What are our } \\
\text { aims? }\end{array}$ & $\begin{array}{l}\text { What is the nature of this } \\
\text { organisation? How can we } \\
\text { achieve our purpose? }\end{array}$ \\
\hline Key Processes & DIALOGUE \ & $\begin{array}{l}\text { NEGOTIATION OF } \\
\text { SHARED PURPOSE }\end{array}$ & SENSE MAKING \\
\hline $\begin{array}{l}\text { STRUCTURE \& } \\
\text { PROCESSES }\end{array}$ & $\begin{array}{l}\text { - Roles: formal \& informal } \\
\text { - Career pathway } \\
\text { - Networks \& relationships } \\
\text { - Knowledge of the system } \\
\text { - Personal and professional } \\
\text { credibility }\end{array}$ & $\begin{array}{l}\text { - Work groups, committees } \\
\text { \& partnerships } \\
\text { - Devolution of mgmt \& } \\
\text { leadership } \\
\text { - Distribution of roles and } \\
\text { functions }\end{array}$ & $\begin{array}{l}\text { - HR systems (e.g. recruit- } \\
\text { ment, reward, performance } \\
\text { mgmt, succession planning) } \\
\text { - Resources: financial, } \\
\text { human, space, other } \\
\text { - Communication channels }\end{array}$ \\
\hline Key Questions & $\begin{array}{l}\text { Where do I want to be \& } \\
\text { how can I get there? }\end{array}$ & $\begin{array}{l}\text { How are our activities } \\
\text { aligned to those of the or- } \\
\text { ganisation? }\end{array}$ & $\begin{array}{l}\text { Where does the power lie \& } \\
\text { what are the blocks to } \\
\text { change? }\end{array}$ \\
\hline Key Processes & ROLES ४ ४ & FUNCTIONS ४ & SYSTEMS 4 \\
\hline $\begin{array}{l}\text { LEADERSHIP } \\
\text { DEVELOPMENT }\end{array}$ & $\begin{array}{l}\text { - Devt of human capital } \\
\text { - Reflection } \\
\text { - Practice } \\
\text { - Self awareness \& } \\
\text { confidence } \\
\text { - Skills and knowledge } \\
\text { - Mastery } \\
\text { - Personal support (coaching } \\
\text { \& mentoring) }\end{array}$ & $\begin{array}{l}\text { - Devt of social capital } \\
\text { - Teambuilding } \\
\text { - Identity work \& creation of } \\
\text { shared social identity }\end{array}$ & $\begin{array}{l}\text { - Devt of organisational } \\
\text { capital } \\
\text { - Org. development: restruc- } \\
\text { turing \& change } \\
\text { - Mgmt development: opera- } \\
\text { tional capability, stability \& } \\
\text { consistency } \\
\text { - Lship development: strategic } \\
\text { capability, innovation \& } \\
\text { change } \\
\text { - Leadership pipeline }\end{array}$ \\
\hline Key Questions & $\begin{array}{l}\text { How can I make sense of } \\
\text { my experience? }\end{array}$ & $\begin{array}{l}\text { How can we build collective } \\
\text { capacity? }\end{array}$ & $\begin{array}{l}\text { How can we facilitate en- } \\
\text { gagement with leadership? }\end{array}$ \\
\hline Key Processes & REFLECTION & EXPERIMENTATION $\triangleleft \cdots$ & LEARNING \\
\hline $\begin{array}{l}\text { LEARNING } \\
\text { TRANSFER }\end{array}$ & $\begin{array}{l}\text { - Personal support } \\
\text { - Opportunities to apply } \\
\text { learning } \\
\text { - Progression opportunities } \\
\text { - Relevance to work/life } \\
\text { situation } \\
\text { - Professional credibility }\end{array}$ & $\begin{array}{l}\text { - Inclusive work methods } \\
\text { - Peer learning \& support } \\
\text { - Ongoing work-based learn- } \\
\text { ing }\end{array}$ & $\begin{array}{l}\text { - Removing barriers } \\
\text { - System-wide perspective } \\
\text { - Creating a learning culture } \\
\text { - Ongoing commitment \& } \\
\text { support } \\
\text { - Putting in place new systems }\end{array}$ \\
\hline Key Questions & $\begin{array}{l}\text { How can I make an impact } \\
\text { within the system? }\end{array}$ & $\begin{array}{l}\text { How can we support one } \\
\text { another more effectively in } \\
\text { our work? }\end{array}$ & $\begin{array}{l}\text { How can these new practices } \\
\text { be embedded in the organisa- } \\
\text { tion? }\end{array}$ \\
\hline Key Processes & EXPERIENCE & ADAPTATION $\triangleleft \cdots \cdots \cdots \cdots$ & $E M B E D D I N G$ ४ \\
\hline $\begin{array}{l}\text { EVALUATION \& } \\
\text { REVIEW }\end{array}$ & $\begin{array}{l}\text { - Personal transformation } \\
\text { - Developing others } \\
\text { - Through life development }\end{array}$ & $\begin{array}{l}\text { - Maintaining continuity in } \\
\text { change } \\
\text { - Building trust and collabo- } \\
\text { ration }\end{array}$ & $\begin{array}{l}\text { - Metrics \& indicators } \\
\text { - Future orientation } \\
\text { - Learning organisation } \\
\text { - Celebrating success }\end{array}$ \\
\hline Key Questions & $\begin{array}{l}\text { How can I continue to grow } \\
\& \text { develop? }\end{array}$ & $\begin{array}{l}\text { How can we improve on } \\
\text { what we are already doing? }\end{array}$ & $\begin{array}{l}\text { Where should the organisa- } \\
\text { tion go next? }\end{array}$ \\
\hline Key Processes & PERSONAL CHANGE & IMPACTS & TRANSFORMATION \\
\hline
\end{tabular}

Figure 1 - An Integrated Framework for Leadership Development 
(4) The fourth step is about learning transfer. Without application to, and implementation in, the work and life context of individuals and organisations leadership development will fail to bear fruit. Thus individual leaders will require ongoing support, opportunities to apply their learning, and the ability to be recognised as credible in front of their peers and colleagues. They need to take stock of their situation and discover how they can influence the system from their position within it. Groups may find that where several members have engaged in the same development process a greater momentum for change may be sustained through opportunities for peer learning, discussion, joint projects and a shared vocabulary about leadership. For organisations, the transfer involves embedding the learning within organisational systems and processes, eliminating barriers, developing a sense of community and the establishment of new systems and processes where required. Fundamentally, to be effective leadership development requires long-term top-level support and investment and an ongoing commitment to supporting and developing participants.

(5) Finally, the leadership development process requires evaluation and review. Without personal transformation, sharing the learning with others and a commitment to lifelong learning individuals will not maximise on the value of their development. Likewise, at the group and organisational levels there should be attempts to identify success, future needs and requirements and meaningful measures and indicators of impact and performance. Given the mediated and time-dependent nature of many of these impacts the measures will need to be qualitative as well as quantitative, which together can be used to create a compelling story or account of why and how the development initiative gave rise to such outcomes and how this might change in the future.

Each of these steps is interconnected such that they influence the others, affect the overall context and help define future directions and priorities. Undoubtedly, proposing an integrated approach such as this is far easier said than done but the message is simple: without taking a holistic, system-wide perspective on LMD the potential benefits will be severely limited. LMD needs to be considered as a key strategic concern, endorsed and supported from the very top of the organisation, with implications for everyone, at all levels.

\section{Summary and conclusions}

In this chapter I have attempted to outline the manner in which leadership, management and organisational learning and development are connected and, how through considering them as parts of the same process we may be able to enhance the integration and consistency of approaches, thereby improving the likelihood that investments will be worthwhile.

It has also been argued that there has been a massive expansion of LMD supply and demand over recent years, with an increasing tendency towards customised, flexible and experiential initiatives. Despite this trend, however, the realities of LMD are subject to a number of pressures and tensions that mean that individuals and organisations may not always invest in the most effective forms of provision and that providers may find it difficult to deliver precisely what is required. Indeed, evidence of a causal link between LMD and organisational performance remains elusive, however, it would appear that where initiatives are well thought through and aligned with strategic processes and priorities they are far more likely to produce positive and enduring results.

In thinking through how organisations determine an appropriate approach to LMD, they would be well advised to consider the theoretical and philosophical assumptions upon which different forms of provision are based, and to articulate a clear rationale as to how LMD may lead to enhanced individual, group and/or organisational capability and subsequently impact upon performance. To assist readers in deciding upon an LMD provider a number of points of guidance are provided.

The chapter concludes with an integrated framework for leadership development that highlights some of the key issues and questions that organisations, groups and individuals are advised to consider when attempting to line up organisational, leadership and management development.

A large amount of material has been covered and it is possible that this chapter will have raised more questions than it has answered. The exploration of such questions however, I would argue, is the most fundamental part of the enquiry. Developing leaders, managers and organisations is ultimately a process that emerges through collective dialogue. It is the 
shared meanings, understandings, identities and purpose that hold organisations together. There is no Holy Grail or quick fix but through working together as critical and reflective practitioners we may find new, more efficient, inclusive and sustainable ways of growing, structuring and running our organisations.

\section{Notes}

${ }^{1}$ McCauley, C., Moxley, R. and VanVelsor, E. (1998) The Center for Creative Leadership Handbook of Leadership Development, San Francisco: Jossey-Bass. pp 228-9.

${ }^{2}$ Raelin, J. (2004) Don't bother putting leadership into people, Academy of Management Executive, 18, 131-135.

${ }^{3}$ Financial Times (2003) Companies still value training, Financial Times, Monday September $8^{\text {th }}$, Special Report on Business Education.

${ }^{4}$ Higher Education Statistics Agency (2008) Student tables by subject of study 1996/7 and 2006/7, URL: [www.hesa.ac.uk], accessed 09/06/08.

${ }^{5}$ Mabey, C. and Ramirez, M. (2004) Developing Managers: A European Perspective. London: Chartered Management Institute.

${ }^{6}$ Adapted from: West, M. and Jackson, D. (2002) Developing school leaders: a comparative study of school preparation programmes. Paper presented at AERA Annual Conference, New Orleans,

${ }^{7}$ Hirsh W and Carter A (2002) New Directions in Management Development, IES Report 387, Brighton: Institute for Employment Studies.

${ }^{8}$ Storey, J. (2004) Changing theories of leadership and leadership development. In J. Storey (eds) (2004) Leadership in Organizations: Current issues and key trends. London: Routledge. p.27

${ }^{9}$ Burgoyne, J., Hirsh, W. and Williams, S. (2004) The Development of Management and Leadership Capability and its Contribution to Performance: the evidence, the prospects and the research need. London: Department for Education and Skills, Research Report 560. p.49

10 Maurer, T. J., Barbeite, F.G., \& Mitchell, D.R. (2002). Predictors of attitudes toward a 360-degree feedback system and involvement in post-feedback management development activity, Journal of Occupational and Organizational Psychology, 75, 87-108.

${ }^{11}$ Burgoyne, et al. (2004) op cit.

12 Chia, R. (1996) Teaching paradigm shifting in management education: university business schools and entrepreneurial imagination, Journal of Management Studies, 33(4): 409 - 428.

13 Holman, D. (2000) Contemporary models of management education in the UK, Management Learning, 31(2), 197-217.

${ }^{14}$ Clarke, M., Butcher, D. and Bailey, C. (2004) 'Strategically aligned leadership development' In J. Storey (ed.) Leadership in Organizations: Current issues and key trends. London: Routledge. p.271-292.

15 Day, D. (2000) Leadership development: a review in context, Leadership Quarterly, 11(4), 581-613. p582.

${ }^{16}$ Ibid: p583.

17 Campbell, D., Dardis, G. and Campbell, K. (2003) Enhancing incremental influence: a focused approach to leadership development, Journal of Leadership and Organizational Studies, 10(1), 29-44.

18 Ibid: p31

${ }^{19}$ Gosling, J. (2004) Leadership development in management education, Business Leadership Review 1(1). URL: [www.mbaworld.com/ blrissues/article1.htm], p.5

${ }^{20}$ Gosling, J. and Mintzberg, H. (2004) The education of practicing managers, Sloan Management Review, 45(4), 19-22.

21 lbid: p22.

22 The Center for Creative Leadership's 70-20-10 model of leadership development $(70 \%$ on the job learning, $20 \%$ interpersonal feedback and $10 \%$ formal training courses) is now used as a framework for development in organisations including Mars, Lilley, Thompson Reuters and ITT.

${ }^{23}$ Yukl, G. (2006) Leadership in Organizations ( $6^{\text {th }}$ edition). Upper Saddle River: Pearson Prentice Hall.

24 West-Burnham, J. (1998) 'Identifying and diagnosing needs'. In J. West-Burnham and F. O'Sullvan (Eds.) Leadership and Professional Development in Schools. London: Financial Times/Prentice Hall. p99

${ }^{25}$ Purcell, J., Kinnie, N., Hutchinson, S., Rayton, B. and Swart, J. (2003) Understanding the people and performance link: unlocking the black box. London: CIPD - cited in Burgoyne et al., 2004: 37

${ }^{26}$ Gill, R. (2006) Theory and Practice of Leadership. London: Sage Publications.

${ }^{27}$ Buckingham, M. (2005) What Great Managers DO. Harvard Business Review, 83(3), 70-79.

${ }^{28}$ Purcell, J., Kinnie, N., Swart, J., Rayton, B. and Hutchinson, S. (2008) People Management and Performance. London: Routledge.

${ }^{29}$ Bolden, R. (ed.) (2006) Leadership Development in Context. Leadership South West Research Report, Centre for Leadership Studies, Exeter. URL [www.centres.ex.ac.uk/cls/research/publish.php]. 